\title{
The Use of Drop-Structures to Increase the Dissolved Oxygen Level along the Cibarani Channel
}

\author{
Jonathan Wijaya, Doddi Yudianto, Finna Fitriana* \\ Department of Civil Engineering, Parahyangan Catholic University, Bandung, INDONESIA \\ Jalan Ciumbuleuit No. 94, Hegarmanah, Cidadap, Bandung City, West Java \\ *Corresponding authors: finnafitriana@unpar.ac.id
}

SUBMITTED 18 Maret 2021 REVISED 13 September 2021 ACCEPTED 10 October 2021

\begin{abstract}
The Cikapundung river basin community uses the Cibarani channel as a drainage system and water source for fishing. However, the test result released on $9^{\text {th }}$ November 2020 revealed that the channel's water quality failed to reach the class II raw water standards due to various domestic waste discharges. This led to the performance of various studies to identify pollution control techniques by limiting the wastewater discharge and quality, controlling the intake discharge, and using baffles. The Cibarani channel has a dropstructure that can improve the water quality, though the effect has not been previously detailed. Therefore, this study was intended to comprehensively examine the effect of the drop-structure along the Cibarani channel to improve water quality conditions, specifically the Dissolved Oxygen (DO) parameter. This study employed the one-dimensional HEC-RAS software to simulate the hydrodynamic and water quality conditions along the Cibarani channel, and the drop-structure was modelled using two alternatives consisting of a vertical wall and a steep riverbed. Subsequently, the drop-structure fitted with a vertical wall gave a more plausible reaeration rate of 125 day ${ }^{-1}$ and Root Mean Square Error (RMSE) value of 0.50. The placement of a similar configuration before the first housing of the channel increased the DO concentrations by an average of $4.37 \mathrm{mg} / \mathrm{L}$. This was followed by the modelling of another drop-structure after the first housing to increase the DO levels at the downstream part. Eventually, the combination of the two new drop-structures succeeded in increasing the DO concentrations along the Cibarani channel to $3.3-6.9 \mathrm{mg} / \mathrm{L}$.
\end{abstract}

KEYWORDS Dissolved Oxygen; Drop-Structure; HEC-RAS; Reaeration Rate; Water Quality Modelling.

(c) The Author(s) 2022. This article is distributed under a Creative Commons Attribution-ShareAlike 4.0 International license.

\section{INTRODUCTION}

Cikapundung is one of the rivers located strategically in Bandung City, used by the community and government for several purposes, including recreational sports and as a clean water source. Meanwhile, the developments in Bandung City have led to some changes in the Cikapundung river basin (Bachrein, 2012), such as population growth, which resulted environmental problems such as water pollution (Rahayu et al., 2018).

Cibarani is one of the Cikapundung river basin channels which water is exploited for irrigational purposes. However, its function has changed into a drainage system for the wastewater of the community. This has led to a decrease in the water quality of the Cibarani channel. Currently, the water is turbid and produces a foul odour, which inconveniences the surrounding community.
The Cibarani channel is classified to be consistent with class II of the raw water standards in article 55 of Government Regulation No. 82 of 2001. Subsequently, two studies have been performed on improving the Cibarani water quality. They involved raising the discharge, limiting the wastewater discharge and quality, and using baffles (Trisnojoyo, 2017; Hayhera, 2019). Generally, the Cibarani irrigation has several water structures, such as a culvert, gutter, weirs, and a drop-structure. The downstream part of this drop-structure experienced a change from supercritical to subcritical flow, resulting in a hydraulic jump, which may increase air entrainment that could affect the water quality (Arief, 2014). However, these two studies did not simulate the drop-structure in the Cibarani channel, though previous investigations suggested that drop-structures can increase the 
water quality (Damarany et al., 2009; Triane and Suharyanto, 2015).

Therefore, this study aimed at evaluating the effect of a drop-structure on the water quality parameters along the Cibarani channel based on another sampling. The second aim was to model and simulate the drop-structure configuration for improving the dissolved oxygen, using HEC-RAS software to simulate hydraulic and water quality analyses.

This study comprised three scopes, first, the investigated area spanned $1.3 \mathrm{~km}$, from the Cilimus weir intake to its downstream parts, as seen in Figure 1. Second, HEC-RAS 4.1 was used to conduct the hydraulic and water quality analyses. Third, various nutrient parameters, such as Biochemical Oxygen Demand (BOD), Total Nitrogen (TN), and Total Phosphorous (TP) were tested, though the model focused on the Dissolved Oxygen parameter.

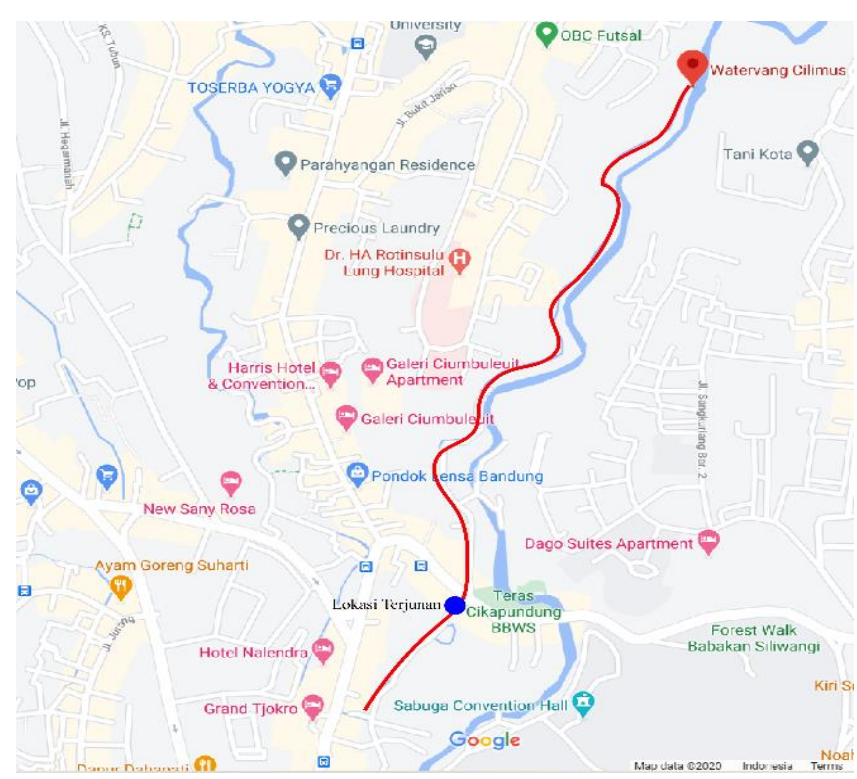

Figure 1. Study location.

\section{METHOD}

HEC-RAS is utilized by the U.S. Army Corps of Engineers and can be used freely. It can evaluate four analysis components, namely steady flow water surface profile, unsteady flow simulation, sediment transport boundary computations, and water quality (Brunner and CEIWR-HEC, 2010). Generally, the hydrodynamic condition in the Cibarani channel is simulated only in steady-state conditions as the flow can be adjusted from the Cilimus weir intake. This HEC-RAS steady-state condition uses the energy equation and iterative method of the standard step to calculate the water surface profiles. Meanwhile, the water quality analysis performed by the program is based on the conservation of mass. For this modelling, HECRAS evaluates nine nutrient parameters, namely Algae, Dissolved Oxygen, Carbonaceous BOD, Organic Nitrogen, Ammonium Nitrogen, Nitrite Nitrogen, Nitrate Nitrogen, Organic Phosphorus, and Orthophosphate.

The basis of the water quality analysis is the conservation of mass, which uses the depletion of oxygen for its estimation. The equation assumes that BOD has a first-order degradation reaction and deoxygenation rate $\left(k_{d}\right)$ of the Ohio river (Streeter and Phelps, 1925).

Streeter-Phelps equation

$\bar{u} \frac{\mathrm{d} C}{\mathrm{~d} x}=-k_{d} L+k_{a}\left(C_{s}-C\right)$

The mass balance equation in the Streeter-Phelps calculation can be modified to describe the ultimate BOD and DO deficits reactions.

Mass balance equation from Streeter-Phelps formula:

$\frac{\mathrm{d} C}{\mathrm{~d} t}=-\bar{u} \frac{\mathrm{d} C}{\mathrm{~d} x}-k_{d} L+k_{a}\left(C_{s}-C\right)$

Mass balance equation for ultimate BOD and DO deficit:

$\frac{\mathrm{d} L}{\mathrm{~d} t}=-\bar{u} \frac{\mathrm{d} L}{\mathrm{~d} x}-k_{d} L$

$\frac{\mathrm{d} D}{\mathrm{~d} t}=-\bar{u} \frac{\mathrm{d} D}{\mathrm{~d} x}-k_{d} L+k_{a} D$

Where $\bar{u}$ is the average flow velocity in crosssection, $C$ is the DO concentration, $L$ is the ultimate BOD concentration, $C_{s}$ is the saturated dissolved oxygen concentration, $\mathrm{D}$ is the $\mathrm{DO}$ deficit concentration, $k_{d}$ is the first order deoxygenation rate constant, and $k_{a}$ is the first order reaeration rate constant.

The formula above can be modified with mass balance equations for advective and dispersive systems. This is because dispersion is essential for 
distributing oxygen, as well as for various morphological changes, slopes, pools, riffles, drop-structure, and large turbulent eddies (Yudianto and Xie, 2008).

The mass balance equations for the advective and dispersive systems:

$\frac{\mathrm{d} C}{\mathrm{~d} t}=-\bar{u} \frac{\mathrm{d} C}{\mathrm{~d} x}+E_{x} \frac{\mathrm{d}^{2} C}{\mathrm{~d} x^{2}}-k_{d} L+k_{a}\left(C_{s}-C\right)$

$\frac{\mathrm{d} C}{\mathrm{~d} t}=-\bar{u} \frac{\mathrm{d} C}{\mathrm{~d} x}+E_{x} \frac{\mathrm{d}^{2} C}{\mathrm{~d} x^{2}}-k_{d} L+k_{a}\left(C_{s}-C\right)$

$\frac{\mathrm{d} D}{\mathrm{~d} t}=-\bar{u} \frac{\mathrm{d} D}{\mathrm{~d} x}+E_{x} \frac{\mathrm{d}^{2} D}{\mathrm{~d} x^{2}}-k_{d} L+k_{a} D$

where $E_{x}$ is longitudinal dispersion coefficient.

The reaeration rate used the empirical equation developed by Jha et al. (2001) for the upper and lower channel streams, alongside the trial-anderror method and the drop-structure. Tables 1 and 2 show the range of reaeration rate values in the physical drop-structure models.

Reaeration rate equation from Jha et al. (2001)

$k_{a(20)}=5.792 \frac{\sqrt{\bar{u}}}{H^{0.25}}$

where $k_{a(20)}$ is the reaeration rate at temperature $20^{\circ} \mathrm{C}$, and $H$ is the average water depth in crosssection.

The deoxygenation rate depends on the type of waste disposed to the water and was used as a calibration variable since it is not measured in the laboratory (Ji, 2008).

Table 1. Reaeration rate values from Ughbebor et al. (2012)

\begin{tabular}{ll}
\hline Types of water bodies & $\begin{array}{l}\text { Value of } k_{a} \\
\left(\text { day }^{-1}\right)\end{array}$ \\
\hline Small pond & $0.05-1.0$ \\
Sluggish streams/lakes & $1.0-1.5$ \\
Large streams with low velocity & $1.5-2.0$ \\
Large streams with moderate & $2.0-3.0$ \\
velocity & \\
Swift Streams & $3.0-5.0$ \\
Rapids & $>5.0$ \\
\hline
\end{tabular}

Table 2. Reaeration rate values from Peavy, Rowe, and Tchobanoglous (1985)

\begin{tabular}{ll}
\hline Stream type & $\begin{array}{l}k_{a} \text { at } 20^{\circ} \mathrm{C} \\
\left(\text { day }^{-1}\right)\end{array}$ \\
\hline $\begin{array}{l}\text { Sluggish river } \\
\text { Large river of low velocity }\end{array}$ & $0.23-0.35-0.46$ \\
$\begin{array}{l}\text { Large stream of normal } \\
\text { velocity }\end{array}$ & $0.46-0.69$ \\
$\begin{array}{l}\text { Swift streams } \\
\text { Rapids and waterfalls }\end{array}$ & $0.69-1.15$ \\
\hline
\end{tabular}

The longitudinal dispersion coefficient applied in this study was delivered by one-dimensional simulation. Consequently, Fischer's (1975) equation gave the best result of DO curves (Kashefipour and Falconer, 2002).

Dispersion coefficient from Fischer's (1975) equation

$E_{x}=0.011 \frac{\bar{u}^{2} B^{2}}{H U_{*}}$

Where $B$ is channel width, and $U_{*}$ is shear velocity. The water quality rates are influenced by temperature, usually specified at $20^{\circ} \mathrm{C}$. Therefore, a correction with the Arrhenius rate law is required by using the relationship between the water quality rates and temperature.

$k_{T}=k_{20} \theta^{(T-20)}$

Where $k_{T}$ is the rate constant at temperature $T, k_{20}$ is the rate constant at temperature $20^{\circ} \mathrm{C}$, and $\theta$ is the temperature correction coefficient.

In this study, the evaluations of the observed data with the modelled data were calculated using Root Mean Square Error (RMSE). The value of RMSE close to zero indicates that the modelled data can deliver more accurate results.

RMSE equation

$R M S E=\sqrt{\frac{1}{N} \sum_{i=1}^{N}\left(x_{i}-\hat{x}_{i}\right)^{2}}$

Where RMSE is Root Mean Square Error, $N$ is some observational data, $x_{i}$ is observational value, $\chi_{i}$ is modelled value. 
The sampling points indicated in this study comprised six water stations along the channel and five wastewater inlets. Figures 2 and 3 show the channel scheme and locations of the sampling, respectively. The water was collected from the sampling points and measured during the dry season on the $9^{\text {th }}$ November 2020, while the wastewater was collected and evaluated on the $17^{\text {th }}$ and $24^{\text {th }}$ November 2020. Figure 4 presents the sampling conditions.

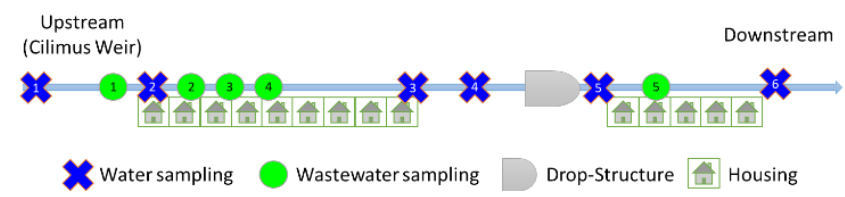

Figure 2. Cibarani channel scheme.

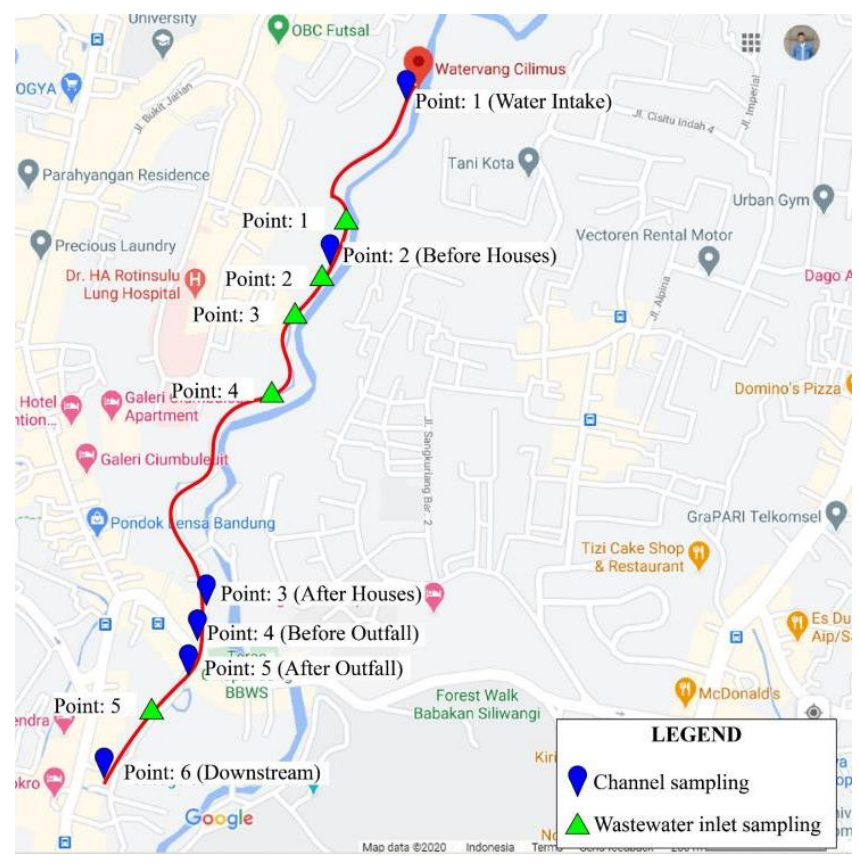

Figure 3. Sampling locations.

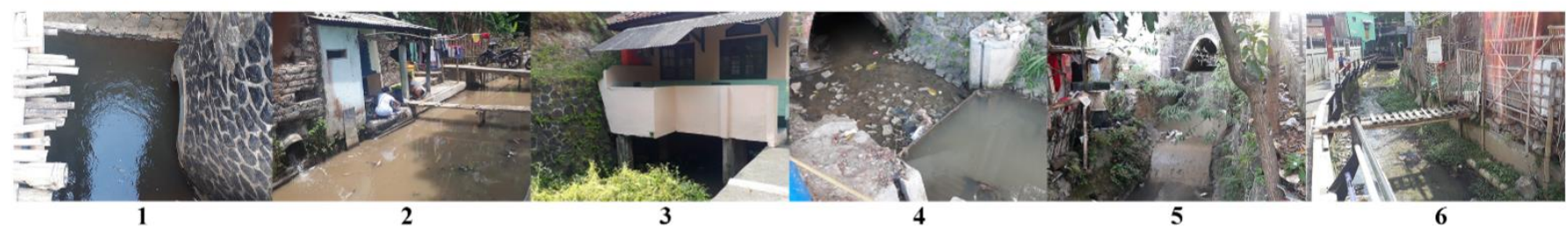

(a)

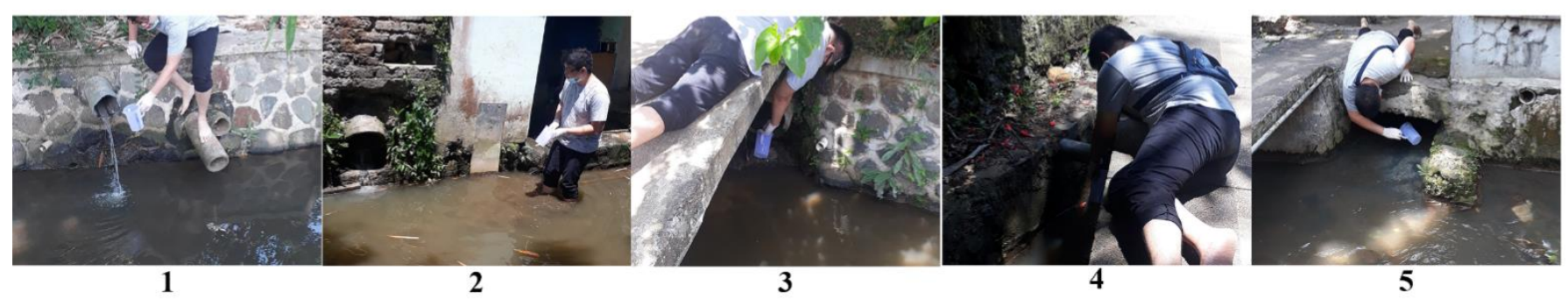

(b)

Figure 4. The condition of sampling points (a) along the channel (b) in the wastewater inlet. 
Also, the hydraulic data along the channel, consisting of velocity, water depth, and crosssection, were collected and measured. The velocity and water depth were determined using the current meter and a ruler, respectively, while the cross-sectional data of the channel was collected from a previous study of the Cibarani channel. The hydraulic data used in this study are presented in Table 3. Since the channel's flow is constant, a steady flow simulation was employed, while the water quality, which was the only changing variable, was represented by the Dissolved Oxygen (DO) parameter. It was measured directly on-site using a dissolved oxygen probe to generate a more accurate result. The Dissolved Oxygen (DO) parameter data for each sampling point are shown in Table 4 .

Table 3. Hydraulic data (a) along the channel (b) in the wastewater inlet

(a)

\begin{tabular}{lllll}
\hline \multicolumn{5}{c}{ Cibarani channel } \\
\hline Date & Points & $\overline{\mathrm{U}}$ & $\mathrm{H}$ & $\mathrm{Q}$ \\
& & $\mathrm{m} / \mathrm{s}]$ & {$[\mathrm{m}]$} & {$\left[\mathrm{m}^{3} / \mathrm{s}\right]$} \\
\hline $09 / 11 / 2020$ & 1 & 0.470 & 0.100 & 0.02000 \\
& 2 & 0.060 & 0.130 & 0.02023 \\
& 3 & 0.200 & 0.115 & 0.02046 \\
& 4 & 0.100 & 0.175 & 0.02059 \\
& 5 & 0.090 & 0.133 & 0.02060 \\
& 6 & 0.165 & 0.070 & 0.02560 \\
\hline
\end{tabular}

(b)

\begin{tabular}{lcl}
\hline \multicolumn{3}{c}{ Wastewater inlet } \\
\hline Date & Points & $\begin{array}{l}\mathrm{Q} \\
{\left[\mathrm{m}^{3} / \mathrm{s}\right]}\end{array}$ \\
\hline $17 / 11 / 2020$ & 1 & 0.000304 \\
& 2 & 0.000171 \\
& 3 & 0.000213 \\
& 4 & 0.000008 \\
$24 / 11 / 2020$ & 5 & 0.005000 \\
& 1 & 0.000157 \\
& 2 & 0.000290 \\
& 3 & 0.000048 \\
& 4 & 0.000007 \\
& 5 & 0.005000 \\
\hline
\end{tabular}

Table 4. Wastewater quality data (a) along the channel, (b) in the wastewater inlet

\begin{tabular}{llllll} 
(a) & \multicolumn{5}{c}{ (b) } \\
\hline \multicolumn{3}{c}{ Cibarani channel } & \multicolumn{3}{c}{ Wastewater inlet } \\
Date & Points & C & Date & Points & C \\
& & {$[\mathrm{mg} / \mathrm{L}]$} & & & {$[\mathrm{mg} / \mathrm{L}]$} \\
\hline $09 / 11$ & 1 & 6.0 & $17 / 11$ & 1 & 1.9 \\
2020 & 2 & 4.0 & 2020 & 2 & 0.3 \\
& 3 & 0.8 & & 3 & 2.3 \\
& 4 & 0.9 & & 4 & 5.9 \\
& 5 & 2.8 & & 5 & 2.0 \\
& 6 & 1.3 & $24 / 11$ & 1 & 3.9 \\
& & & 2020 & 2 & 3.9 \\
& & & & 3 & 1.5 \\
& & & & 4 & 6.4 \\
& & & & 5 & 2.0 \\
\hline
\end{tabular}

The drop-structure in the HEC-RAS program can be modelled with inline weir or cross-sections. Meanwhile, two types of drop-structures were simulated in this study to give plausible results of the hydrodynamic and water quality aspects. However, the two types were a vertical wall and a steep riverbed, also their longitudinal sections are shown in Figure 5.

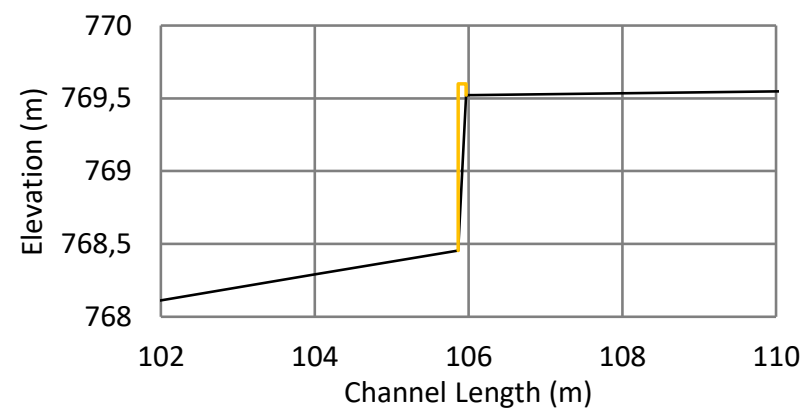

(a)

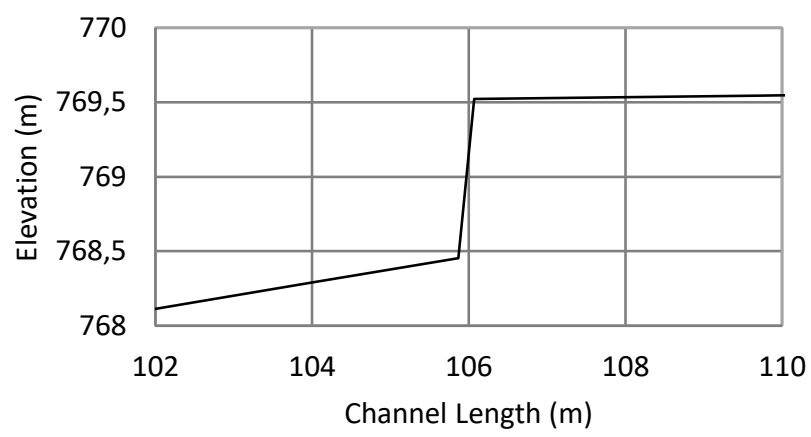

(b)

Figure 5. Longitudinal section of the (a) vertical wall (b) steep riverbed as the drop-structures. 


\section{RESULTS AND DISCUSSION}

\subsection{Hydrodynamic Calibration}

Manning's roughness coefficient for the Cibarani channel was set to 0.023 , according to the "Open Channel Hydraulics” by Chow (1959). Conversely, some parts of the channel filled with garbage were set at 0.05 due to the increase in the coefficient value. The HEC-RAS hydrodynamic modelling results were presented with the water surface (WS) and velocity profile along the channel from the different drop-structure models, as presented in Figures 6 and 7, respectively. According to the tests, the water depths from both drop-structure configurations ranged from 0.05 to $0.98 \mathrm{~m}$, while the velocities ranged from 0.009 to $4.3 \mathrm{~m} / \mathrm{s}$. Hence, the hydrodynamic modelling in this study can represent the actual condition as the water depth and velocity RMSE value for both dropstructure configurations gave the exact value of 0.06 and 0.24 , respectively. This signified that the water quality analysis could be conducted to determine the drop-structure configuration. The RMSE values of both drop-structures are shown in Table 5

Table 5. Water surface and velocity RMSE

\begin{tabular}{lll}
\hline Points & \multicolumn{2}{l}{ Vertical wall and steep riverbed } \\
\cline { 2 - 3 } & WS & Velocity \\
\hline 1 & 0.03 & 0.13 \\
2 & 0.05 & 0.11 \\
3 & 0.09 & 0.56 \\
4 & 0.01 & 0.02 \\
5 & 0.11 & 0.02 \\
6 & 0.00 & 0.03 \\
RMSE & 0.06 & 0.24 \\
\hline
\end{tabular}

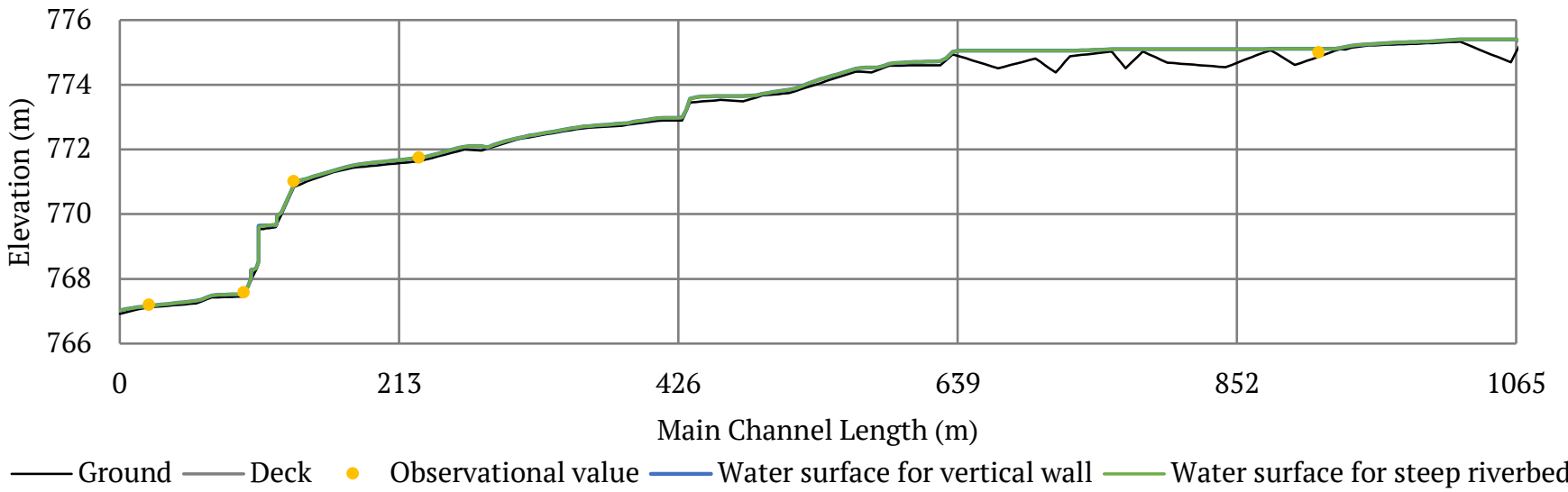

Figure 6. Water surface profiles.

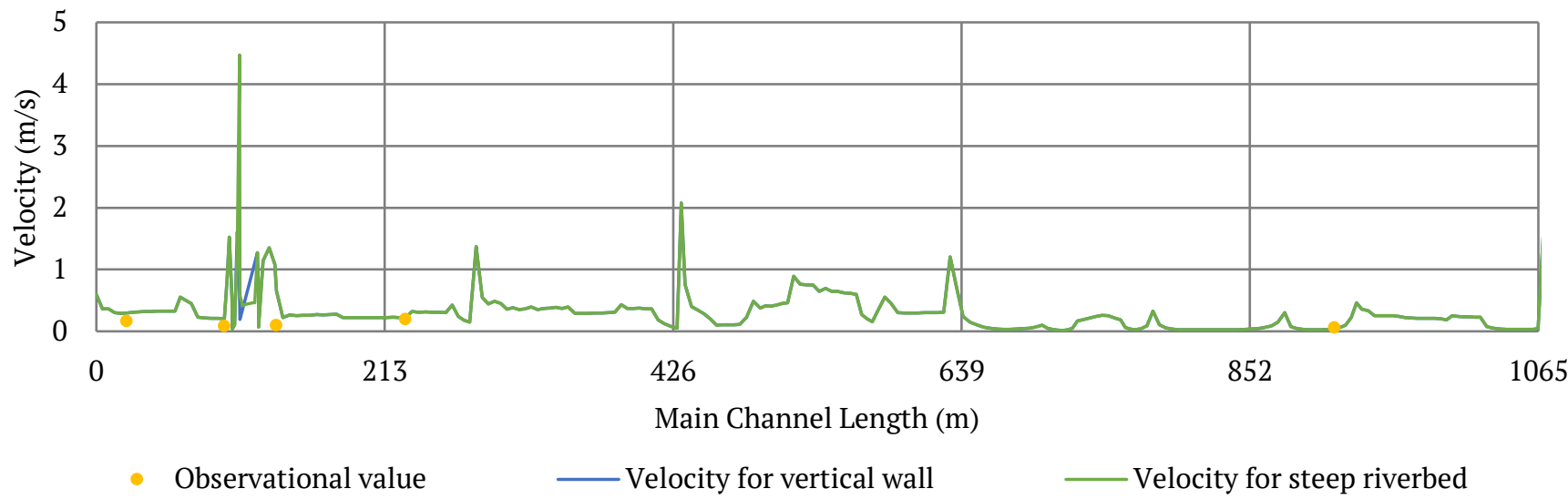

Figure 7. Velocity profiles. 


\subsection{Existing Water Quality Conditions}

The values of the reaeration rate and dispersion coefficient, which are a function of velocity and water depth, were divided into three sections, namely first housing, drop-structure, and the second housing. Table 6 presents the dispersion coefficient values for each section and the type of drop-structure.

Table 6. Dispersion coefficient values of calibration process

\begin{tabular}{lll}
\hline Section & $\begin{array}{l}\text { Vertical wall } \\
{\left[\mathrm{m}^{2} / \mathrm{s}\right]}\end{array}$ & $\begin{array}{l}\text { Steep riverbed } \\
{\left[\mathrm{m}^{2} / \mathrm{s}\right]}\end{array}$ \\
\hline First housing & 0.082 & 0.082 \\
Drop-structure & 0.160 & 0.485 \\
Second housing & 0.216 & 0.216 \\
\hline
\end{tabular}

Subsequently, the dispersion coefficients for each model and section, other parameters, as well as the initial and boundary conditions were needed for the water quality analysis. The initial conditions were acquired from the water quality data at the Cilimus weir intake, while the boundary conditions were obtained from the measurements at the wastewater inlets. In this study, the samples were collected at 08:00 a.m. to represent the time of wastewater discharge, as the normal discharge time is between 06:00 a.m. to 10:00 a.m., based on the residents' interviews. The reaeration rate values in the housing sections were estimated using the empirical equation from Jha et al. (2001), as it gives the best DO curve results. However, it could not be used for the drop-structure section, leading to the application of the trial-and-error method. The reaeration rates were different in both types of dropstructures, as the values were generated mainly based on velocity and water depth, though these parameters remained constant in the observational points. Hence, the reaeration rate values of the mathematic model using HEC-RAS and the physical model differed from Tables 1 and 2. The values for each section and type of the drop-structure are shown in Table 7.

Table 7. Reaeration rate values of the calibration process

\begin{tabular}{lll}
\hline Section & $\begin{array}{l}\text { Vertical wall } \\
{\left[\text { day }^{-1}\right]}\end{array}$ & $\begin{array}{l}\text { Steep riverbed } \\
{\left[\text { day }^{-1}\right]}\end{array}$ \\
\hline First housing & 3.044 & 3.044 \\
Drop-structure & 125.0 & 135.0 \\
Second housing & 4.267 & 4.267 \\
\hline
\end{tabular}

The drop-structure sections employed the same method in obtaining the reaeration rate and deoxygenation, which had no laboratory measurement. At 3.15 day $^{-1}$, the deoxygenation rate could give the best $\mathrm{DO}$ curve results ranging from the HEC-RAS suggestion limit of 0.02 to 3.40 day $^{-1}$.

Figure 8 shows the DO simulation curves of three drop-structure types from the calibration process. Their average water quality measurements were obtained by running the model for seven days. Table 8 presents the RMSE of the modelled values with the observed data.

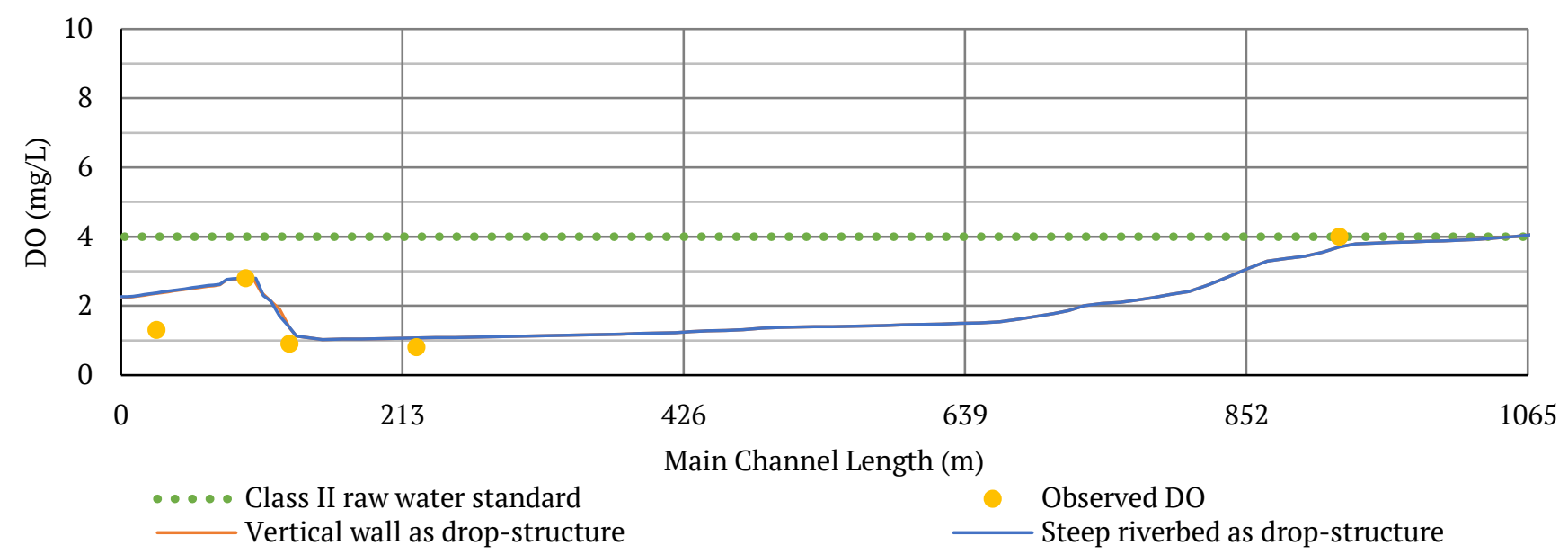

Figure 8. DO curve with the different types of drop-structure. 
Table 8. The RMSE values of the calibration process

\begin{tabular}{lll}
\hline Points & $\begin{array}{l}\text { Vertical } \\
\text { wall }\end{array}$ & $\begin{array}{l}\text { Steep } \\
\text { riverbed }\end{array}$ \\
\hline 1 & 0.00 & 0.00 \\
2 & 0.30 & 0.30 \\
3 & 0.27 & 0.27 \\
4 & 0.47 & 0.48 \\
5 & 0.02 & 0.00 \\
6 & 1.06 & 1.08 \\
RMSE & 0.50 & 0.51 \\
\hline
\end{tabular}

The range of RMSE values from 0.50 to 0.51 for each type of drop-structure displayed in Table 8 indicates that the HEC-RAS water quality model can simulate the DO curves. Meanwhile, the vertical wall drop-structure generated a better RMSE value of 0.50 . Although the reaeration rate was above the recommended value from the HECRAS program, this type of drop-structure can represent the actual conditions. This led to the use of the vertical wall in this study. According to Figure 8 , the DO value showed a $210 \%$ increase from $0.9 \mathrm{mg} / \mathrm{L}$ to $2.8 \mathrm{mg} / \mathrm{L}$ after the water flowed through an existing drop-structure located $100 \mathrm{~m}$ from the downstream part. However, the structure could not increase the value of DO to 4.0 $\mathrm{mg} / \mathrm{L}$. This necessitates an improvement through the use of an additional drop-structure to elevate the DO values along the channel.

\subsection{An Additional Drop-Structure at the First Housing}

The simulation result in Figure 8 shows that the DO values failed to reach the class II of raw water standards. Therefore, this study tried to improve the DO values by adding a drop-structure in two possible places. First, a new drop-structure was placed before the first housing, around $200 \mathrm{~m}$ to the downstream part from the Cilimus weir intake. Then, the second, new drop-structure was placed after the first housing, around $1000 \mathrm{~m}$ downstream from the Cilimus weir intake. Both schemes can be seen in Figure 9.

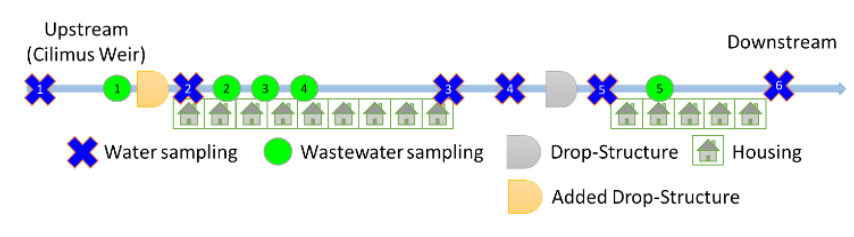

(a)

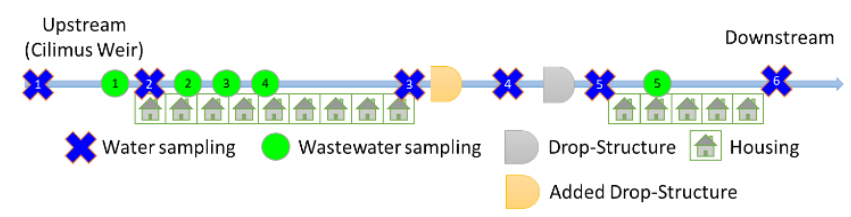

(b)

Figure 9. Scheme of additional drop-structure (a) before the first housing (b) after the first housing.

Changes in the reaeration rate and dispersion coefficient were recorded after modelling the new drop-structure. These parameters were obtained using the same procedure as the calibration process, while the deoxygenation rate was estimated exactly at 3.15 day $^{-1}$. The dispersion coefficient and reaeration rate for each place are listed in Tables 9 and 10.

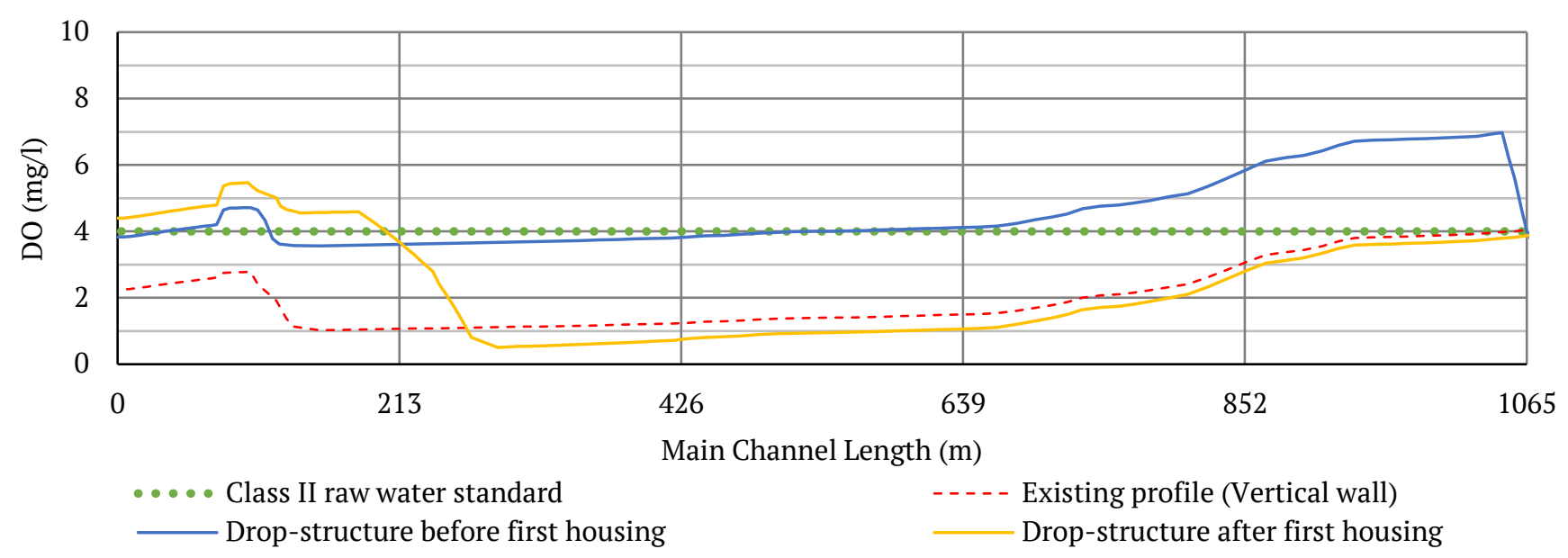

Figure 10. DO curve of the new drop-structure 
Table 9. Dispersion coefficient and reaeration rate of the new drop-structure before the first housing

\begin{tabular}{lll}
\hline Section & $E_{x}\left[\mathrm{~m}^{2} / \mathrm{s}\right]$ & $k_{a}\left[\right.$ day $\left.^{-1}\right]$ \\
\hline Before housing & 0.00067 & 0.887 \\
New drop-structure & 0.00163 & 125 \\
First housing & 0.096 & 3.371 \\
Existing & 0.108 & 125 \\
drop-structure & & \\
Second housing & 0.216 & 4.267 \\
\hline
\end{tabular}

Table 10. Dispersion coefficient and reaeration rate of the new drop-structure after the first housing

\begin{tabular}{lll}
\hline Section & $E_{x}\left[\mathrm{~m}^{2} / \mathrm{s}\right]$ & $k_{a}\left[\right.$ day $\left.^{-1}\right]$ \\
\hline First housing & 0.056 & 2.629 \\
New drop-structure & 0.073 & 125 \\
After first housing & 0.211 & 5.237 \\
Existing & 0.124 & 125 \\
drop-structure & & \\
Second housing & 0.213 & 4.267 \\
\hline
\end{tabular}

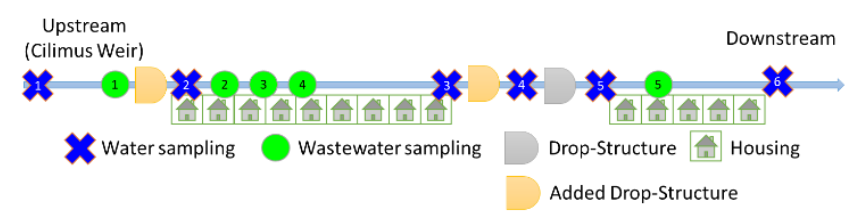

Figure 11. Scheme of the additional drop-structures before and after the first housing.

Table 11. Dispersion coefficient and reaeration rate of the new drop-structures before and after the first housing

\begin{tabular}{lll}
\hline Section & $E_{x}\left[\mathrm{~m}^{2} / \mathrm{s}\right]$ & $k_{a}\left[\right.$ day $\left.^{-1}\right]$ \\
\hline Before housing & 0.00067 & 0.886 \\
New drop-structure & 0.00148 & 125 \\
First housing & 0.063 & 2.867 \\
New drop-structure & 0.073 & 125 \\
After first housing & 0.224 & 5.273 \\
Existing & 0.124 & 125 \\
drop-structure & & \\
Second housing & 0.216 & 4.267 \\
\hline
\end{tabular}

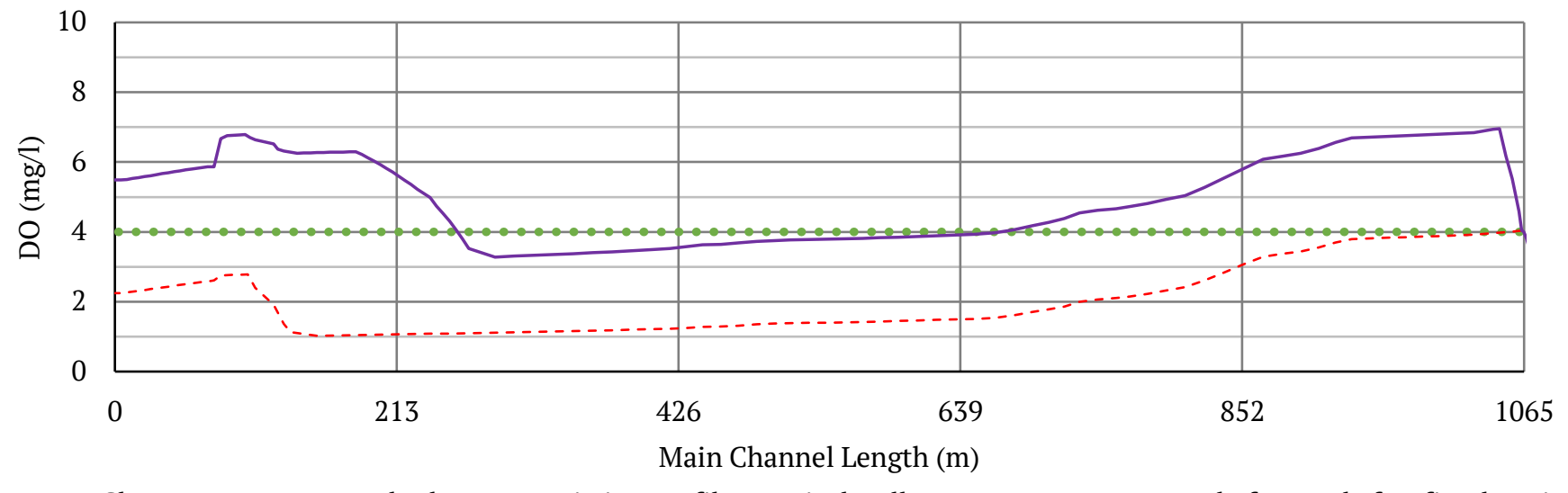

Class II raw water standard - - - - Existing profile (Vertical wall) Drop-structure before and after first housing

Figure 12. DO curve of the two new drop-structures. 
The DO curves in Figure 10 indicate that the additional drop-structure after first housing could affect the DO value at the upstream part because of the limited cross-sections. A difference in DO value of around 10\% signified that an additional drop-structure before the first housing is enough to improve the DO profile along the channel. Also, an additional dropstructure after the housing could improve the DO value for the second housing section. This led to the completion of the study analysis through the placement of two drop-structures along the channel.

\subsection{Additional Drop-Structure Before and After the First Housing}

As shown in Figure 11, this section involved an additional drop-structure before and after the first housing to observe the improvement of the DO value along the channel and around the downstream part. Table 11 presents the dispersion coefficient and reaeration rate for each section.

The DO curve results for the two additional dropstructures are shown in Figure 12. According to the illustration, the average DO value increased by $88 \%$ from $2.6 \mathrm{mg} / \mathrm{L}$ to $4.9 \mathrm{mg} / \mathrm{L}$. The values at the downstream part of the channel also elevated by $135 \%$ from $2.3 \mathrm{mg} / \mathrm{L}$ to $5.4 \mathrm{mg} / \mathrm{L}$. Therefore, the best combination to improve the DO value along the channel is placing two drop-structures before and after the first housing.

\section{CONCLUSION}

According to the water test results, the Cibarani channel fell short of class II of raw water standards with an average DO value of $2.6 \mathrm{mg} / \mathrm{L}$. The DO concentrations increased from 0.9 to 2.8 $\mathrm{mg} / \mathrm{L}$ after the water flowed through a dropstructure near Siliwangi Street. Subsequently, this study conducted a water quality simulation using the vertical wall type of drop-structure. This technique produced a smaller RMSE value and a more suitable reaeration rate of 125 day $^{-1}$ than the other configuration, despite a significant difference in the reaeration rate value between the mathematicians' estimation and the physical model. Although an additional drop-structure at the channel's upper stream was enough to improve the averaged DO values, the downstream part of the channel still needed improvement. This led to the combination of a drop-structure before and after the first housing to significantly increase the DO concentrations between the ranges of 3.3 to $6.9 \mathrm{mg} / \mathrm{L}$ along the channel to reach the class II raw water standards. Meanwhile, further observation and data collection are needed to improve and obtain better study results.

\section{DISCLAIMER}

The authors declared no conflict of interests.

\section{AVAILABILITY OF DATA AND MATERIALS}

All data are available from the author

\section{AUTHOR CONTRIBUTION STATEMENTS}

All authors conceived and designed the study. Jonathan $\mathrm{W}$ performed data collection, hydraulic modelling, and prepared original writing; Finna $\mathrm{F}$ developed the research methodology and model validation; Finna $\mathrm{F}$ and Jonathan $\mathrm{W}$ carried out the water quality test; Finna $\mathrm{F}$ and Doddi $\mathrm{Y}$ developed the concept, review and editing, and visualization. All authors contributed to manuscript revisions. All authors approved the final version of the manuscript and agree to be held accountable for the content therein.

\section{ACKNOWLEDGMENTS}

The author is grateful to the personnel at the Centre of Water Resources Engineering, Parahyangan Catholic University, who provided support, guidance, suggestions, and recommendations during this study. The author is also grateful to other persons that cannot be mentioned individually.

\section{REFERENCES}

Arief, A., 2014. Pengaruh Keberadaan Bendung dan Terjunan pada Konsentrasi Oksigen dalam Air. Jurnal Rekayasa Sipil, 2(2), pp. 154-166.

Bachrein, S., 2012. Pengembangan Daerah Aliran Sungai Cikapundung: Diagnostik Wilayah. Jurnal 
Bina Praja: Journal of Home Affairs Governance, 4(4), pp. 227-236.

Brunner, G. W. \& CEIWR-HEC., 2010. HEC-RAS River Analysis System User's Manual. Davis, CA: Hydrologic Engineering Center.

Damarany, P., Fachrul, M. F. \& Astono, W., 2009. Kajian Kualitas Air Sungai Cipinang Bagian Hilir Ditinjau dari Parameter BOD dan DO menggunakan Model Qual2E. Jurnal Teknologi Lingkungan, 5(2), pp. 62-74.

Government of Indonesia., 2001. Peraturan Pemerintah Republik Indonesia Nomor 82 Tahun 2001 tentang Pengelolaan Kualitas Air dan Pengendalian Pencemaran Air.

Hayhera, F. O. \& Yudianto, D., 2019. Studi Pengaruh Perubahan Kecepatan Aliran Air terhadap Peningkatan Kualitas Air pada Saluran irigasi Cibarani. Bandung, Seminar Nasional Teknik Sumber Daya Air.

Jha, R., Ojha, C. S. P. \& Bhatia, K. K. S., 2001. Refinement of Predictive Reaeration Equations for a Typical Indian River. Hydrological Process, 15, pp. 1047-1060.

Ji, Z. G., 2008. Hydrodynamics and water quality. Modeling River, Lakes, and Estuaries. Hoboken, NJ: Wiley-Interscience.

Kashefipour, S. M. \& Falconer, R. A., 2002. Longitudinal Dispersion Coefficient in Natural Channels. Water Research, 36(6), pp. 1596-1608.
Peavy, H. S., Rowe, D. R. \& Tchobanoglous, G., 1985. Environmental Engineering. New York: McGraw-Hill.

Rahayu, Y., Juwana, I. \& Marganingrum, D., 2018. Kajian Perhitungan Beban Pencemaran Air Sungai di Daerah Aliran Sungai (DAS) Cikapundung dari Sektor Domestik. Jurnal Rekayasa Hijau, 2(1), pp. 61-71.

Triane, D. \& Suharyanto., 2015. Pemodelan Kualitas Air menggunakan Model QUAL2K (Studi Kasus: DAS Ciliwung). Jurnal Teknik Lingkungan, 21(2), pp. 190-200.

Trisnojoyo, R. R., Yudianto, D. \& Wijaya, O. T., 2017. Studi Estimasi Beban Limbah Cair pada Saluran Irigasi menggunakan HEC-RAS. Bandung, Seminar Nasional Teknik Sumber Daya Air.

Ughbebor, J. N., Agunwamba, J. C. \& Amah, V. E., 2012. Determination of Reaeration Coefficient K2 for Polluted Stream as a Function of Depth, Hydraulic Radius, Temperature and Velocity. Nigerian Journal of Technology, 31(2), pp. 174-180.

Yudianto, D. \& Xie, Y., 2008. The Development of Simple Dissolved Oxygen Sag Curve in Lowland Non-Tidal River by using Matlab. Journal of Applied sciences in Environmental Sanitation, 3(3), pp. 137- 
[This page is intentionally left blank] 